\title{
3.7. HUMAN RESOURCE DEVELOPMENT WITHIN THE OPERATIONAL PROGRAMME KNOWLEDGE EDUCATION DEVELOPMENT
}

\begin{abstract}
Summary
The subject of this article is the main instrument of the European Communities social policy, i.e. European Social Fund (ESF) in the new 2014-2020 perspective. The main purpose of the publication is to present new challenges for human resource development for Poland in the new Operational Programme. At the beginning, the European Social Fund was presented in certain phases of growth. Then the concept of human resource development is explained. In the further part, the new programming period 2014-2020 is described. The last part discusses the Operational Programme Knowledge Education Development (OP KED) responsibility for all ESF interventions in Poland in 2014-2020 and it lists the challenges for Polish human resource development. Considerations of the paper are based on the review of Polish and foreign literature studies from the field of the European Social Fund and development of human resources.
\end{abstract}

Keywords: European Union, European Social Fund, human resource development, Poland.

\section{Introduction}

For many years a growing interest in the EU funds has been noted. The funds could be obtained for widely understood investments in human capital. This is shown not only by the growing number of implemented EU projects, but also by the increasing number of different types of institutions that use the funding from the European Union. Poland, being a full-fledged member of the Union, has also become a recipient of the financial assistance, which serves the implementation of the European cohesion policy. A fundamental instrument of social policy of the European Communities, whose intervention aims are long-term and long-range, consisting of investment in human capital linked to the improvement of competitiveness of regions and growth of entrepreneurship, is the European Social Fund. It is an instrument of the modern human resource development policy with a focus on contributing to achievement of socio-economic cohesion.

Poland, in the first programming period 2004-2006, received 12,8 billion Euro, which represented more than half of the EU funds for the ten new Member States. For implementation of operations in the framework of the European Social Fund Poland received 2,043 billion Euro, of which $71 \%$ was dedicated to implementation of the Sectoral Operational Development Programme of Human Resources. In the financial perspective for the period 2007-2013 Poland with the amount of 68 billion Euro 
became the largest beneficiary of the EU funds among all the Member States of the European Union. A programme that took the whole intervention within the framework of the European Social Fund (ESF) in 2007-2013 is the Human Capital Operational Programme (HC OP), implementation of which would cost 11,429 billion Euro. In the newest period 2014-2020, Poland will receive 82,5 billion Euro from the cohesion budget. As a result of decentralization of the European Social Fund in Poland in the years $2014-2020,72 \%$ of this Fund will be assigned to the regional operational programmes, and $28 \%$ to the Knowledge, Education and Development Operational Programme- KED OP (Ministry of Infrastructure and Development, 2014). ESF allocation into the KED OP will make 4.166,8 billion Euro and 252, 4 million Euro within the framework of the specific budget line for the Employment of Young People Initiative. In this context, a question arises about the importance of the European Social Fund as an instrument of human resource development. Thus, the main subject of interest in this article is the European Social Fund (ESF), and the main purpose of this article is to present human resource development within new Operational Programme in the 2014-2020 period.

The structure of this article is to smoothly reach its aim. At the beginning, the European Social Fund was presented in certain phases of growth. Then, the concept of human resource development is explained. In the further part, new programming period 2014-2020 is described. The last part indicates the Operational Programme Knowledge Education Development (OP KED) responsible for all ESF interventions in Poland in 2014-2020 and it lists the challenges for Polish human resource development. Considerations of the paper are based on the review of Polish and foreign literature studies from the field of the European Social Fund and development of human resources.

\section{European Social Fund - the phases of growth}

The European Social Fund (ESF) is one of the five European Structural and Investment Funds (ESIF). The European Social Fund (ESF) was created in 1958 on the basis of the European Economic Community Treaty as the first structural fund of the European Communities (European Commission, 1958). In the initial period the ESF was to increase the chances of obtaining work in the community by promoting employment and increasing the mobility of workforce. Starting in the sixties, the ESF has evolved many times adjusting to the changes in the economic and social cohesion policy and according to the broader social policy of the EU that mainly concerned employment (Grewiński, 2003).

From the very beginning of the functioning the Fund focused on the creation of mechanisms to support development of the labour market. The original idea was to support the national labour market policies. On the basis of the subsequent reforms the actions of ESF began to incorporate the transnational objectives (Kubisz, 2001). To a large extent the role of the Fund resulted from the establishment of the European Regional Development Fund (ERDF) in 1975, which took over the tasks related to the promotion of economically backward regions (Auleytner, 1997). 
The years 2000-2006 were a new activity period for the ESF. Its entire potential was joined on the level of all Member States in order to implement the priority tasks of the European Employment Strategy. The fundamental pillars of the Strategy were: improvement of employability, development of entrepreneurship, improvement of adaptability of businesses and their employees (Zarębski, 2010). The ESF was to support the Member States of the European Union in the field of implementation of modern, active employment policies and the systems aimed at providing financial support for the up-skilling of workers (Sobotka, 2001).

On the basis of Regulation 1784/1999/EC of the European Parliament and of the Council of Europe on 12 July 1999, the Fund shall support actions oriented to prevent and counteract the unemployment and to develop the human potential and social integration of the labour market, to promote the growth of employment, equal opportunities for men and women, harmonious and sustainable development and economic and social cohesion. The Fund shall support actions within the implementation of the European Employment Strategy. The European Social Fund is therefore a fundamental instrument of the structural policy of the European Union, which is to serve the implementation of the employment policy and development of human resources.

\section{Theoretical concept of employee development and human resource development}

For the clarity of considerations presented in this article, it is necessary to explain the key concepts such as employee development and human resource development. In Polish literature on the subject there is no agreement as for the one, common definition of the concept human resource development (HRD) or employee development. The term employee development was defined by $\mathrm{T}$. Listwan as one of the first Polish researchers. According to Listwan it is the process of preparation to carry out tasks and occupy positions of greater complexity and responsibility (Listwan, 1998). A. Pocztowski on the other hand clarifies that employee development is the intentional configurations of knowledge enrichment ventures, abilities development, shaping the values, attitudes, motivation and skills, as well as taking care of physical and mental health of those carrying out the work, which measures lead to the increase of its efficiency and the market value of human resources (2013). H. Król understands employee development as a group of activities in the field of knowledge enrichment, development of skills and abilities, development of motivation and physical and mental health of employees, which should lead to the increase in their personal human capital and the value of organizational capital (2006). The above mentioned examples reflect the narrow approach to HRD in which development is treated as an element of human resource management.

Different point of view holds J. Strużyna who considers human resource development as a concept which is tightly linked to the subject of human resource management, yet it is not equivalent. According to the researcher human resource development, has exceeded the traditional functions of human resource management and entered the field of a specific type of management style (OD) (2008). Through the review of foreign literature Strużyna argues that HRD developed simultaneously with human 
resource management, creating three main research areas: organizational development, career development, and training and employee development. It is the exemplification of a broad approach to development of human resources.

In the English literature there are two terms regarding the above described development of human resources: employee development, which is equivalent to a narrow approach to employee development (Garavan et al., 2008, p. 615) and human resource development (HRD), which reflects the broader definition of human resource development (Garavan, Costin \& Heraty, 1996). The author of this article, pointing to the challenges of the new programming period 2014-2014, included both the narrow and the wider context of human resource development.

\section{New 2014-2020 programming period in the European Union - main areas of support}

In 2014-2020 European Union will have allocated more than 80 billion euro into the European Social Fund. Its allocations amount to $24.8 \%$ of the Structural Funds budget. The minimum share that has been introduced for the first time in 2014 effectively marks the end to the gradual decrease of the ESF share for the past 25 years. 18 Member States have decided to allocate additional funds to the ESF beyond the minimum share.

In the financial perspective for the period 2014-2020 the legal basis for the ESF is provided by Regulation No 1304/2013 of the European Parliament. The main tasks of the ESF in current period consist of support of the following priorities:

1. promoting employment and supporting labour mobility;

2. promoting social inclusion and combating poverty;

3. investing in education skills and lifelong learning;

4. enhancing institutional capacity and efficient public administration.

Within the tasks of the first Priority, the ESF will support organizations around the EU to put in place projects focused on training people and helping them obtain employment. Initiatives supporting entrepreneurs with start-up funding and companies that need restructuring or lack qualified workers will also be financed. Helping young people enter the labour market will be the top priority for the ESF in all EU countries. Within this Priority a great emphasis is placed on combating youth unemployment. A special action - Youth Employment Initiative has been thus introduced. This will help young unemployed lacking education or training in regions where youth unemployment rate is above $25 \%$. At least $€ 6.4$ billion will come as support of Member States to guarantee putting the youth program into practice.

The second Priority relates to the social inclusion, which is strongly connected with employment as the most effective way of giving people independence, financial security and a sense of belonging. The ESF will continue to finance many thousands of projects that help people in difficulty and those from disadvantaged groups to get qualifications and jobs and have the same opportunities as others. At least $20 \%$ of the Fund has been allocated to social inclusion, which will mean that the underprivileged will get more support to guarantee them equal opportunities with others and to integrate into society. 
The Priority number three is equal to better education. Across the EU the ESF is financing initiatives to improve education and training and ensure young people finish their education and get the skills that make them more competitive on the job market. Reducing school drop-out is the main concern here, along with improving vocational and tertiary education opportunities.

The last Priority emphasizes stronger public administration. The ESF will support Member States' actions to improve the quality of public administration and governance and so support their structural reforms by giving them the necessary administrative and institutional capacities.

\section{Polish European Social Fund Operational Programme in 2014 - 2020}

Member States transfer the objectives included in the documents of the EU onto the local ground in the form of relevant entries in the National Strategic Reference Framework (NSRF) and Operational Programs (OP). Operational Programmes (OP) break down the overarching strategic objectives agreed in the Partnership Agreement into investment priorities, specific objectives and further into concrete actions.

In the 2014-2020 perspective the whole intervention of ESF will have been taken over by the Operational Programme Knowledge Education Development (OP KED) and the Youth Employment Initiative (YEI), whose total value amounts to EUR 4.689 billion of which EUR 4.436 billion is from the EU budget including EUR 252 million from the Youth Employment Initiative. They contribute to addressing the key challenges which Poland faces in the fields of employment, social inclusion, health, education and public administration. This Operational Programme will support measures in line with the priorities of the Europe 2020 Strategy to guarantee smart, sustainable and inclusive growth. Furthermore, it will directly support interventions addressing the challenges outlined in the Country-Specific Recommendations. This ensures investments particularly in the integration of the young people labour market with a focus on vocational education and training and on participation of women in the labour market. Investments will cover the following main areas:

- promoting sustainable and quality employment and supporting labour mobility;

- promoting social inclusion and combating poverty;

- investing in education, skills and lifelong learning;

- enhancing institutional capacity and efficient public administration.

The main beneficiaries of the planned actions are: central government bodies, territorial self-government bodies and municipalities, courts and judiciary institutions, social partners and relevant civil sector organisations. The OP will focus on systemic measures at national level and will be complemented by regional OPs, which will provide complementary individual support (Ministry of Infrastructure and Development, 2014).

The Knowledge Education Development Operational Programme consists of 6 Priorities, at both central and regional levels, within which the institutions managing the individual priorities announce competitions for funding activities aimed at investment in human resources. 
Allocations for particular Priorities within the framework of the Knowledge Education Development Operational Programme are presented in the Table 1.

Table 1. Allocations in the framework of the KED Operational Programme

\begin{tabular}{|l|r|}
\hline \multicolumn{1}{|c|}{ Priority } & $\begin{array}{c}\text { Allocation } \\
\text { (million EUR) }\end{array}$ \\
\hline I.Youth on the labour market & 1757 \\
\hline II.Effective public policy for labour market, economy and education & 739 \\
\hline III.Tertiary education for economy and development & 1056 \\
\hline IV.Social innovations and cross- border cooperation & 670 \\
\hline V.Healthcare assistance & 301 \\
\hline VI.Technical assistance & 164 \\
\hline
\end{tabular}

Source: Ministry of Infrastructure and Development, 2014

One of the major challenges connected with the field of human resource development which Poland has to face in the current programming period are:

Undertaking long-term development activities by the SME sector. The research conducted by PARP (Polish Agency for Enterprise Development) indicates that only $12 \%$ of enterprises in Poland have development strategy (PARP, 2010) and 26\% of medium-sized enterprises have a strategy for human resource development. The above factors affect the generally low demand for developing services by the SME sector, which in turn influences the low rate of working adults' participation in lifelong learning. Therefore, effective use of the EFS funds for employee education and training on the regional level requires implementation of educational actions addressed to management staff and owners of enterprises. The actions shall be preceded by a complex analysis of development needs and should be carried out with an active engagement of social partners.

Implementation of complex solutions based on demand approach allowing for quality assurance and monitoring of the services offered by training institutions. Investment in human resources is conducted by constantly the same and limited group of SME. The results of studies show that the policy of human resource development in SME should on one hand, make easier access to training for the enterprises which want to invest in their staff and on the other hand, it should increase the level of demand for development services of enterprises which so far have not been interested, do not see such need nor are they aware of such services benefits which in fact are directly linked to their development. The above measure should take into account both microeconomic dimension (improvement of the company's competitive advantage as a result of investment in human resources) and structural - macroeconomic (generating demand for development of development services characterized by adjustment ability to the structural changes in the economy). In this context it is necessary to introduce comprehensive solutions, enabling assurance and quality control services provided by training institutions. 
Making equal access to lifelong learning for adults, including those with low skills. Poland among other European Union countries is negatively distinguished by the adults' low level of qualification and engagement into expanding and filling qualifications after completion of formal education. The percentage of people aged 2564, participating in formal and informal education in Poland equals $21 \%$ and that is lower by half compared to the $41 \%$ average for the OECD countries. As much as $68 \%$ of workers indicate that they do not see the need for their professional qualifications advancement. The increase of adult participation in education (including those with low skills) and strengthening education and vocational counselling (development of tools, preparation of personnel, online support system), as well as development of the offer of schools in the local community (especially in rural areas and small towns) addressed to adults have therefore become the major challenges in this area.

Support of cooperation between universities and businesses, strengthening the proemployment role of higher education. In Poland, the percentage of people aged 30-34 who completed higher education is among the highest in Europe, at the level $40.5 \%$. Higher education is an asset on the labour market. The percentage of unemployed graduates with higher education equals $22 \%$ and is significantly lower compared to the group of vocational schools graduates at the level of $48.3 \%$ or general secondary schools alumni amounting to $49 \%$. Yet, the room for improvement is visible in the area of adaptation of higher education to the needs of the labour market and employers. Thanks to the implementation of the National Qualifications Framework for Higher Education, the higher education institutions restored autonomy to create educational programs. It is therefore necessary to strengthen the involvement of employers in the education process and the implementation of high-quality internship programs. Accurate identification of market needs and actions aiming at assistance in contact of students with employers can contribute to reducing the significantly long period of undertaking work immediately after graduation. With respect to this matter, especially academic career offices and other institutions within the environment of universities should be taken advantage of (Ministry of Infrastructure and Development, 2014).

\section{Conclusions}

Studies on the literature of the subject suggest the growing importance of the European Social Fund as an instrument of human resource development. For the 2014-2020 programming period the following results will have been expected:

- the most disadvantaged persons in an especially difficult situation on the labour market will have a greater chance to actively enter the labour market;

- ESF funds will contribute to reduction in the level of unemployment, to support youth employment and creation of micro-enterprises;

- owing to the ESF interventions people on the labour market and those entering it will have the skills matching to a greater extent the needs of employers;

- interventions undertaken by the ESF will improve conditions for running a business, including enhancement of the business environment of enterprises and improvement of strategic management quality. 


\section{References}

1. Auleytner, J. (1997): Polityka społeczna - teoria a praktyka. Warszawa: WSP TWP.

2. European Commission, (1958): Treaty Establishing the European Economic Community.

3. Garavan, T., Costine, P., Heraty, N. (1996): The emergence of strategic human resource development. Journal of European Industrial Training, Nr 19(10), p. 4-10.

4. Garavan, T., Wilson, O., Cross, Ch., Carbery, R.(2008): Mapping the context and practice of training, development and HRD in European call centers. Journal of European Industrial Training. Tom 32 (Nr 8/9), p. 612-728.

5. Grewiński, M. (2001): Europejski Fundusz Społeczny jako instrument integracji socjalnej Unii Europejskiej, TWP, Warszawa, 298 p.

6. Grewiński, M. (2003): Przygotowania Polski do absorbcji funduszy strukturalnych Unii Europejskiej, Instytut Europejski, Warszawa.

7. Król, H., Ludwiczyński, A. (2006): Zarządzanie zasobami ludzkimi, tworzenie kapitału ludzkiego organizacji, Wydawnictwo PWN, Warszawa, 704 p.

8. Kubisz, M. (2001): Europejski Fundusz Społeczny - szansa i wyzwania dla Polski, MPiPS, Warszawa.

9. Listwan, T. (1998): Kształtowanie kadry menedżerskiej firmy, Wydawnictwo Kadry. Wrocław, $180 \mathrm{p}$.

10. Ministry of Infrastructure and Development (2014): Program Operacyjny Wiedza Edukacja i Rozwój 2014-2020 PO WER 2014-2020, MID, Warszawa.

11. Pocztowski, A. (2013): Zarządzanie zasobami ludzkimi, Polskie Wydawnictwo Ekonomiczne, Warszawa, $460 \mathrm{p}$.

12. Polish Agency for Enterprise Development (2010): Inteligentne organizacje- zarządzanie wiedzą i kompetencjami pracowników, PAED, Warszawa.

13. Regulation No 1784/1999 of the European Parliament and of the Council of 12 July 1999.

14. Regulation No 1304/2013 of the European Parliament.

15. Sobotka, K. (2001): Zasady korzystania z funduszy europejskich na rzecz rozwoju zasobów ludzkich, Instytut Europejski, Łódź.

16. Strużyna, J., Bratnicki, M., Majowska, M., Ingram, T. (2008): Rozwój zarządzania zasobami ludzkimi, Wydawnictwo Akademii Ekonomicznej, Katowice, 216 p.

17. Zarębski, M. (2010): Rola Europejskiego Funduszu Społecznego w rozwoju zasobów ludzkich, Acta Universitatis Nicoli Copernici, 397, Toruń, p. 111-121. 